\title{
Organic matter quality structures benthic fatty acid patterns and the abundance of fungi and bacteria in temperate lakes
}

Robert Taube (1) https://orcid.org/0000-0003-3136-8732, Lars Ganzert, Hans-Peter Grossart, Gerd Gleixner, Katrin Premke

DOI

10.1016/i.scitotenv.2017.07.256

Original publication date

14 September 2017 (Available online)

Document version

Accepted manuscript

Published in

Science of The Total Environment

Citation (Vancouver)

Taube R, Ganzert L, Grossart H-P, Gleixner G, Premke K. Organic matter quality structures benthic fatty acid patterns and the abundance of fungi and bacteria in temperate lakes. Science of the Total Environment. 2018;610-611:469-81. 
To be submitted in STOTEN

\title{
Organic matter quality structures benthic fatty acid patterns and the abundance of fungi and bacteria in temperate lakes.
}

\author{
Robert Taube ${ }^{1,2}$, Lars Ganzert ${ }^{3}$, Hans-Peter Grossart ${ }^{3,4}$, Gerd Gleixner $^{5}$, Katrin Premke ${ }^{1,2}$
}

1. Leibniz Institute of Freshwater Ecology and Inland Fisheries (IGB), Dept. Chemical Analytics and Biogeochemistry, 12587 Berlin (Germany)

2. Leibniz Centre for Agricultural Landscape Research (ZALF), Institute of Landscape Biogeochemistry, 15374 Müncheberg (Germany)

3. Leibniz Institute of Freshwater Ecology and Inland Fisheries (IGB), Dept. Experimental Limnology, 16775 Stechlin (Germany)

4. Potsdam University, Institute for Biochemistry and Biology, 14469 Potsdam (Germany)

5. Max Planck Institute for Biogeochemistry, Jena (Germany)

Words: 11316; Tables: 2; Figures: 6

\begin{abstract}
Benthic microbial communities (BMCs) play important roles in the carbon cycle of lakes, and benthic littoral zones in particular have been previously highlighted as biogeochemical hotspots. Dissolved organic matter (DOM) presents the major carbon pool in lakes, and although the effect of DOM composition on the pelagic microbial community composition is widely accepted, little is known about its effect on BMCs, particularly aquatic fungi. Therefore, we investigated the composition of benthic littoral microbial communities in twenty highly diverse lakes in northeast Germany. DOM quality was analyzed via size exclusion chromatography (SEC), fluorescence parallel factor analyses (PRAFACs) and UV-Vis spectroscopy. We determined the BMC composition and biomass using phospholipidderived fatty acids (PLFA) and extended the interpretation to the analysis of fungi by applying a Bayesian mixed model. We present evidence that the quality of DOM structures the BMCs, which are dominated by heterotrophic bacteria and show low fungal biomass. The fungal biomass increases when the DOM pool is processed by microorganisms of allochthonous origin, whereas the opposite is true for bacteria.
\end{abstract}




\section{Keywords}

PLFA, PARAFAC, size exclusion chromatography (SEC), aquatic fungi, stable isotopes, FASTAR

\section{Abbreviations}

BMC - benthic microbial community, SEC - size exclusion chromatography, PARAFAC - Parallel factor analysis, HMWS - High molecular weight substances, HS - Humic substances, SUVA - specific ultraviolet absorption

\section{Introduction}

Several studies have recently examined the relationship between the quality and quantity of organic matter (OM) and the composition, activity and physiological state of aquatic heterotrophic microbial communities (Lehman et al., 2010; Strickland and Rousk, 2010; Lange et al., 2015; Fabian et al., 2016). In freshwater ecosystems, both the quality and quantity of OM, which is predominantly composed of dissolved organic matter (DOM), have been shown to control the metabolic activity and composition of microbial organisms (Likens et al., 2009; Attermeyer et al., 2014; Kuehn et al., 2014). Quality is further defined as chemical composition relating to molecular size and molecular complexity. This relationship was confirmed by Findlay et al. (2003), who observed increased metabolic activities accompanied by changes in the benthic microbial community (BMC) when highly bioavailable OM was added. Microbial processing and photodegradation of DOM can cause DOM to flocculate, which may represent an important source of OM in sediments together with sinking particulate organic matter (POM) (Meyers and Ishiwatari, 1993; von Wachenfeldt et al., 2008). DOM can originate from internal primary production within an ecosystem, i.e., autochthonous $\mathrm{OM}$, or from terrestrial inflow and precipitation, i.e., allochthonous OM. In most lentic ecosystems, allochthonous DOM predominates over autochthonous DOM (Wilkinson et al., 2013). An increased abundance of allochthonous DOM causes increases in dissolved organic carbon (DOC) concentrations, decreases in $\mathrm{pH}$ values (Roth et al., 2013, 2014; Larson et al., 2014), and alterations in microbial OM processing (Gudasz et al., 2012) and the structure of bacterial communities (Kritzberg et al., 2006; Ruiz-Gonzalez et al., 2015).

To date, heterotrophic bacteria have been considered the main components of planktonic and benthic carbon cycling in freshwater ecosystems; thus, they have been investigated intensively (Docherty et al., 2006; Judd et al., 2006; Amaral et al., 2016). However, the 
important role of aquatic fungi was revealed in studies on the degradation of leaf and plant litter, particularly in streams (Gessner et al., 2010; Fabian et al., 2016). In the case of leaf degradation, antagonistic effects of both fungi and bacteria have been shown (MilleLindblom and Tranvik, 2003); at the same time, however, bacterial activity and growth are promoted by fungal extracellular enzymatic activities that provide intermediate decomposition products (Romaní et al., 2006)..

The role of fungi in lentic ecosystems is manifold and includes the degradation of leaves, macrophyte litter and pollen, as well as parasitism on algae (Jobard et al., 2010; Wurzbacher et al., 2010, 2014; Monchy et al., 2011; Taib et al., 2013), but these roles are often overlooked (Grossart et al., 2016). However, fungi are present in all lake habitats, particularly in littoral sediments that represent biogeochemical hotspots of carbon cycling (Wurzbacher et al. 2016). Therefore, fungi and bacteria contribute significantly to microbial biomass, productivity and carbon flow (Buesing and Gessner, 2006).

Despite their primarily saprophytic lifestyle, fungi and bacteria are morphologically, physiologically and phylogenetically distinct, which explains their divergent preferences for environmental conditions and dominance in different niches (Grossart and Rojas-Jimenez, 2016). In this context, decreasing bioavailability and nutrient content, decreases in pH have been shown to increase the fungi:bacteria ratio (F:B) in soils and streams (Findlay et al., 2002; Bååth and Anderson, 2003; Rousk et al., 2009), suggesting that pH adaptation is most likely an important trait. Different $F: B$ ratios have severe ecological consequences and may result in different carbon usage efficiencies (CUEs), i.e., the ratio of assimilated biomass carbon to the total carbon consumed, between both microbial groups (del Giorgio and Cole, 1998). Whether the ecological coherence between $\mathrm{F}: \mathrm{B}$ ratios and $\mathrm{OM}$ characteristics and $\mathrm{pH}$ are also important in lake ecosystems remains largely unknown. Evidence of a similar relationship was obtained in a study of 49 Baltic rivers (Jørgensen and Stepanauskas, 2009) and an experiment on lake pollen degradation (Wurzbacher et al., 2014). Both suggest that fungal biomass is positively correlated with OM content.

The lack of simultaneous evaluations of aquatic fungal and bacterial biomass and analyses of their ecological role in aquatic ecosystems can be explained by methodological limitations. Ergosterol is a biomarker for fungi that does not occur in basal fungi such as Chytridiomycota, and it is still present after fungal cell death, which increases the difficulty 
of determining the relationships between aquatic fungi and environmental features (MilleLindblom et al., 2004). Although the analysis of phospholipid-derived fatty acids (PLFAs) allows for a reliable chemotaxonomic differentiation between fungi and bacteria and concurrent analyses of differential carbon sources via stable carbon isotopes in soil samples, aquatic samples are not easily analyzed. Although markers from soil bacteria can be assigned to aquatic bacteria, the soil fungal marker fatty acid C18:2n6,9 also appears in planktonic algae, which makes it unsuitable for reliable fungal biomass determinations in aquatic ecosystems per se. However, a Bayesian mixed model has been successfully applied to complex algal communities to overcome limitations posed by the single marker approach (Willers et al., 2015). For this approach, whole PLFA patterns of several cultured species of the same taxonomic groups need to be summarized. The Bayesian mixed model can then be used to calculate the relative contribution of the different groups in the environmental sample. Instead of focusing on one fatty acid, the model takes ratios between various fatty acids into account and allows for the analysis of taxa that do not possess a specific marker (De Carvalho and Caramujo, 2014; Strandberg et al., 2015). Therefore, extending this method to microbial communities in lake sediments holds the potential to quantitatively and simultaneously differentiate between the biomass of fungi, bacteria and phototrophic organisms.

Over the past several decades, carbon flow in freshwater food webs has been studied using stable isotope analyses (Jones et al., 1998; Grey et al., 2004; Premke et al., 2010). Stable carbon isotopes show minor trophic fractionation and can therefore be used to assess the carbon sources supporting heterotrophic organisms, provided that the potential food sources have distinct isotopic signatures (Fry and Sherr 1984). Most studies have examined the stable isotope ratios in animals and, therefore, the carbon source used by these organisms, but only few studies have focused on the ${ }^{13} \mathrm{C} /{ }^{12} \mathrm{C}$-ratios in microorganisms in the form of PLFA (Boschker et al. 1999, Steger et al. 2011, Fabian et al. 2016).

Research on the interplay between fungi and bacteria and their different ecological roles within aquatic ecosystems, however, is still in a nascent stage. To identify factors that influence bacterial and fungal biomasses in littoral sediments as well as system-related differences, we investigated 20 lentic freshwater ecosystems along a DOC concentration gradient in the glacial landscape of northeast Germany. We hypothesized that DOM quantity 
and quality significantly affect BMC composition and activities and that benthic aquatic fungi represent an important microbial component in lake ecosystems. Therefore, the F:B ratio was assumed to increase in relation to DOC concentrations and sediment carbon content in lake ecosystems.

\section{Materials and Methods}

\section{Field sampling}

Twenty lentic inland waters (lakes and kettle holes) in the glacial landscape of northeast Germany (Figure 1, Table 1) were sampled between 6 October 2014 and 4 November 2014 along a DOC concentration gradient ranging between 5 and $42 \mathrm{mg} \mathrm{Cl}^{-1}$.

Temperature, $\mathrm{pH}$ and conductivity were measured in surface waters using a Multi 3430 multiprobe (WTW GmbH, Weilheim, Germany). In all lakes, water and sediment samples were collected in the littoral zone approximately 1 to $2 \mathrm{~m}$ in front of the reed belt or approximately 1.5 to $3 \mathrm{~m}$ from the lake shore if reed was absent. The effect of drought on the sample sites cannot be excluded for certain lakes but likely did not occur for at least the past two years. The sampling points in the kettle holes were distributed over the entire waterbody to account for their high internal spatial variability. Samples along the shoreline were collected at five different locations per lake, and three samples were collected for each sample location. Ultimately, three pools were formed containing one sample per location.

Surface water samples were collected with a $1 \mathrm{~L}$ plastic flask, and sediment cores were taken at a water depth of 0.5 to $2.5 \mathrm{~m}$ using a sediment corer on a telescope bar (Uwitec, Mondsee, Austria) in PVC tubes (diameter $63 \mathrm{~mm}$ ). All water samples were pooled at equal amounts, immediately pre-filtered through a $500 \mu \mathrm{m}$ mesh to exclude coarse POM, and then filtered through $0.45 \mu \mathrm{m}$ pre-washed cellulose-acetate filters (Sartorius, Göttingen, Germany) using a vacuum pump for further processing (see below). To analyze the sediment samples, the uppermost $2 \mathrm{~cm}$ of each sediment core was sliced with a core cutter because sediments up to $2 \mathrm{~cm}$ have the highest microbial densities (Haglund et al., 2003) and the potential of oxygenation and resuspension within the water column via turbulence (Schallenberg and Burns, 2004; Kleeberg et al., 2013). Slices were pooled at equal weights and stored at $-20^{\circ} \mathrm{C}$ until further processing. 
Water samples for DOC and dissolved nitrogen were immediately frozen in $50 \mathrm{ml}$ glass vials and later analyzed in the lab using an organic carbon analyzer (Shimadzu, TOC-V CPH, Duisburg, Germany). Samples for metal ion analysis were acidified with $\mathrm{HCl}$ and stored at 4 ${ }^{\circ} \mathrm{C}$ until measurements were performed in the lab with an ion chromatograph (ICP icap 6000 series, Thermo Scientific, Cambridge, UK). Concentrations of both ammonium and nitrate were analyzed using a continuous flow analyzer $\left(\mathrm{Scan}^{++}\right.$, Skalar Analytical B.V., Breda, Netherlands). Finally, the soluble reactive phosphorus (SRP) content was quantified by photometry after extraction as described by Murphy and Riley (1962).

\section{Dissolved organic matter composition analysis}

To investigate the origin of the DOM, fluorescence measurements were conducted in $1 \mathrm{ml}$ quartz cuvettes. The reference blank for the spectrometric measurements consisted of freshly prepared ultrapure water (Satorius, Göttingen, Germany). Fluorescence and absorption spectra were measured using an Aqualog-Fluorometer (Horiba, Kyoto, Japan). The fluorescence spectra were measured in $1.58 \mathrm{~nm}$ steps between 212 and $620 \mathrm{~nm}$ and processed as described by Heinz et al. (2015), and the absorption spectra were measured in $5 \mathrm{~nm}$ steps between 230 and $600 \mathrm{~nm}$. Specific ultraviolet absorption at $254 \mathrm{~nm}$ (SUVA) was calculated by dividing the absorption at $254 \mathrm{~nm}$ by the DOC concentration and was expressed in units of $\mathrm{L} \mathrm{mg} \mathrm{C}^{-1} \mathrm{~m}^{-1}$ (Weishaar et al., 2003).

The measurement of excitation emission matrices (EEM) allows for the characterization of DOM according to its fluorescence properties. Parallel factor analysis (PARAFAC or EEMPARAFAC) allows for the relative quantification of fluorescence components, which can be assigned certain molecular properties, for instance a high protein content or high content of humic acids (Stubbins et al., 2014). The spectra were corrected for inner filter effects, Raman calibrated and subsequently analyzed via PARAFAC using MATLAB and the DOMFlour Toolbox according to instructions provided in the attended tutorial of Stedmon and Bro (2008). Briefly, the data set is tested for outliers, and models with increasing numbers of components are tested for their suitability to explain variations, which are tested by performing several validation steps. The model that features the fewest components and best fits the data is chosen. Absorbance data were used to calculate the E2:E3 ratio, slope ratio (SR) and SUVA as described elsewhere (Weishaar et al., 2003; Helms et al., 2008). 
To characterize the main size fraction of DOM, size exclusion chromatography (SEC) and organic carbon and nitrogen detection were performed using an LC-OCD-OND device (Fa.DOC-Labor Huber, Karlsruhe, Germany). Samples were diluted to $5 \mathrm{mg} \mathrm{L}^{-1} \mathrm{DOC}$ based on previous measurements. The chromatographic column has a weak cationic charge that allowed for the quantification of three major DOM fractions separated by charge and molecular size, and their retention time was determined as described by Huber et al. (2011). We obtained three fractions: high-molecular-weight substances (HMWS) containing nonionic molecules, such as polysaccharides, proteins, and amino sugars with an apparent molecular size of > $10 \mathrm{kDa}$; humic substances (HS), such as humic acids, fulvic acids and their breakdown products; and low-molecular-weight substances (LMWS), which present the smallest identifiable fraction and can contain neutral compounds, such as sugars, ketones, aldehydes and amino acids.

\section{Sediment carbon and nitrogen analysis}

For the carbon and nitrogen analyses, frozen sediments were freeze-dried and stored in a desiccator under an acidic atmosphere (vapor of $0.5 \mathrm{~N} \mathrm{HCl}$ ) for four days to remove all inorganic carbonates from the samples. Then, $5 \mathrm{mg}$ of the sediment was packed in tin capsules for each analysis, and the sediment carbon and nitrogen were analyzed with an Elementar Vario EL cube (Elementar Analysensysteme GmbH, Hanau, Germany).

\section{Phospholipid-derived fatty acid extraction and Bayesian mixed model}

PLFAs, which can only be extracted from living biomass, were used as chemotaxonomic markers (White and Tucker, 1969; White et al., 1979). Lipids were extracted from the sediment by incubation with an extraction buffer according to the method of Bligh and Dyer (modified from BLIGH and DYER, 1959). Polar phospholipids were separated from non-polar lipids by solid phase extraction (Bond Elut LRC cartridge 500 mg, Agilent Technologies, Santa Clara, USA) using solvents of increasing polarity (chloroform, acetone, methanol). The fatty acids were then methylated under mild alkaline conditions to fatty acid methyl esters (FAME) (White et al., 1979; Frostegård et al., 2011). A standard of nonadecanoic acid methyl ester (C19:0) was added following solid phase extraction.

FAMEs were quantified in a gas chromatography system (Agilent 6890, Germany) equipped with a mass selective detector (Agilent 5973-N, Germany) and a fused silica capillary column (CP Sil 88 for FAME). The temperature program was the same as that described by Boëchat 
et al. (2014). To compare the retention times and mass spectra and quantify the FAMEs, we used a standard mix (Supelco 37 Component FAME Mix). For the FAMEs that were not included in the standard, equivalent chain lengths (ECLs) were calculated (Hansen and Andresen, 1968; Bannon et al., 1988) and compared, with ECLs described for the same column (Santercole et al., 2012). The calibration curves of similar fatty acids were used for the quantification of FAMEs identified by the ECLs. The $n$-notation was used to describe the structure of FAMEs, i.e., C16:1-n7c, which refers to the number of carbon atoms, number of double bonds, position ( $\omega$-end) and configuration. Few fatty acids are specific to one specific group (Table 2). Specific fatty acids were low in abundance and, with the exception of 115:0, not reliably detectable via isotope ratio mass spectrometry (IRMS) (see below). To analyze the fatty acid isotope signatures using environmental parameters, 115:0 was used as a marker for heterotrophic bacteria, $\mathrm{C} 18: 1 \mathrm{n} 9$ was used as a mixed marker because it is present in all major functional groups and $\mathrm{C} 16: 1 \mathrm{n} 7$ was used as a marker for methanotrophy. For the calculation of total biomass, all quantified fatty acids were summed and divided by the organic carbon content of the sample.

To calculate the contribution of the biomass of fungi, heterotrophic bacteria and phototrophic organisms to the samples, we applied the Bayesian mixing model FASTAR. FASTAR was developed to calculate the resource use of zooplankton and macroinvertebrates (Galloway et al., 2014, 2015) and has been used to differentiate between phototrophs in lake seston (Strandberg et al., 2015). The bases for applying this model are input ratios consisting of mean percentages from various fatty acids with the respective standard deviations for each taxonomic group. The model is therefore likely to be more robust against variations in specific fatty acids between organisms of the same group because such variations are accounted for by the standard deviation. Input ratios collected from various sources (Akinwole et al., 2014; De Carvalho and Caramujo, 2014; Arce Funck et al., 2015; Strandberg et al., 2015) are provided in Supplemental Table 1. Arce Funck et al. (2015) did not provide data regarding PLFA but did provide data about total fatty acids, which also include neutral lipid fatty acids (NLFA). Both PLFA and NLFA contain the same pool of fatty acids; however, the ratios between them can vary (Olsson and Johansen, 2000). The output of the model was analyzed without previous modifications based on the 0.5 percentile. For further analysis, different taxonomic groups belonging to eukaryotes and bacteria were merged within these groups. To compare the output of the model for fungi and bacteria with 
that of previously established methods, we collected sediment samples from Lakes FuKu NE and GRB in July 2016. For the quantification of fungal biomass, we used the ergosterol method as described by Gessner and Schmitt (1996). For the quantification of bacterial abundances we applied bacterial counting with fluorescence microscopy as described by Attermeyer et al. (2013). We normalized bacterial counts and ergosterol values by the PLFA content per gram sediment.

\section{Isotopic analysis}

Stable isotopes were measured for the PLFA, bulk sediment (not measured in Lakes BrLu, GrBu, GRB, DGW and KLK), DOC and POC. Gas chromatography-combustion-isotope ratio mass spectrometry (GC-C-IRMS HP5890 GC, Agilent Technologies, Palo Alto, CA, USA; connected to a IRMS Deltaplus XL, Finnigan MAT, Bremen, Germany; via the combustion interface GC Combustion III Finnigan MAT, Bremen, Germany) was used to analyze the ${ }^{13} \mathrm{C}$ fatty acids as previously described (Kramer \& Gleixner 2006; Augspurger et al. 2008; Kramer \& Gleixner 2008). The ${ }^{13} \mathrm{C}$ values of DOC and POC were measured at the stable isotope facility of the University of California, Davis. The ${ }^{13} \mathrm{C}$ value of sediments was analyzed using a Delta V Advantage isotope ratio mass spectrometer (Thermo-Scientific, Bremen, Germany).

\section{Statistical analysis}

To test the general similarity between the lakes with respect to DOM composition and benthic community, nonmetric multidimensional scaling (NMDS) was performed for the DOM composition and FAME percentages. For DOM analysis, DOC, SEC parameters (SUVA, HS, LMWS, HMWS and C:N of HMWS and HS) and the PARAFAC components were defined for each lake. The distances and dissimilarities were calculated using the data collected and transformed by Wisconsin double standardization using Bray-Curtis distances. To determine whether the similarity of the lakes in the two matrices is comparable, the correlation of the matrices was tested by performing a Procrustes analysis, PROTEST and Mantel test. To identify correlations and dependences between the major carbon parameters, we performed a principal component analysis including quality parameters from SEC, PARAFAC and absorption with quantity parameters for sediment $\mathrm{C}$ and DOC. A canonical correspondence analysis (CCA) was performed to test for the effects of environmental parameters on the relative contribution of the three organism groups quantified by FASTAR. Parameters were selected by forward selection and ecological relevance. Correlations of 
HMWS, HS and SUVA with bacteria and hyphomycetes were higher than observed for any of the PARAFAC components. To avoid redundancies in the quality parameters, PARAFAC compounds were not included because of their correlation with some of the SEC fractions (see Supplemental Figure 1). SRP, sulfate and calcium were included because of their potential influence on algae abundance. NMDS, Procrustes, CCA, PCA, ANOVA and PERMANOVA analyses were conducted with the vegan package (Version2.4-1, https://cran.rproject.org/web/packages/vegan/index.html) in R (Version: 3.2.2, Vienna, Austria, https://www.R-project.org).

Tests for assessing the significance of variations between groups were performed via an analysis of variance (ANOVA) in R. Tests for normality and linear models were also calculated in $\mathrm{R}$.

\section{Results}

\section{Dissolved organic carbon, $\mathrm{pH}$, temperature and oxygen}

The DOC concentrations ranged from 5 to $42 \mathrm{mg} \mathrm{Cl}^{-1}$ in the sampled lakes. DOC values below $6.5 \mathrm{mg} \mathrm{Cl}^{-1}$ were only found in lakes with large surface areas (> $60 \mathrm{ha}$ ) (except KIWu acronym legend in Table 1), low nutrient contents and low sediment carbon concentrations. DOC concentrations below $11 \mathrm{mg} \mathrm{Cl}^{-1}$ were measured in oligotrophic and mesotrophic lakes with surface areas $>6$ ha. DOC concentrations $>11 \mathrm{mg} \mathrm{Cl}^{-1}$ were found in lakes with a small surface area and in the three kettle holes. With the exception of two kettle holes, high DOC concentrations also indicated high concentrations of organic carbon (>25\%) within the sediments, whereas lakes with a low DOC concentration did not necessarily have low sediment carbon contents.

Kettle hole $\mathrm{KH} 259$ dried up two months before the sampling campaign (pers. comm. Florian Reverey) and was in the stage of rewetting during sampling. This location represented the highest concentration of $\mathrm{DOC}$ in this study, with $42 \mathrm{mg} \mathrm{I}^{-1}$. The $\mathrm{pH}$ values of all lakes ranged between 4.5 and 9.1 in the surface water. Lakes with a $\mathrm{pH} \leq 6.5$ had peat bog areas in their catchment and high DOC concentrations of $>16 \mathrm{mg} \mathrm{Cl}^{-1}$. In lakes with alkaline surface water, the sediments were always more acidic than the water by at least 0.5 to $1.5 \mathrm{pH}$ units. Lake temperatures ranged between 11 and $16.6^{\circ} \mathrm{C}$ during our sampling campaign. Oxygen 
saturation in the surface water ranged between 4.8 and $12 \mathrm{mg} \mathrm{O}_{2} \mathrm{I}^{-1}$, indicating that oxygen was generally available.

\section{Dissolved organic matter composition}

DOM quality was determined using size exclusion chromatography. The results revealed that HS contributed between 60 and $80 \%$ of the total DOM for 18 out of 20 lakes. The remaining two lakes strongly deviated from that range by nearly $10 \%$, while Lake KIMi showed $51 \pm 3.9$ $\mathrm{mg} \mathrm{HSI}^{-1}$ and Lake FuKuSW showed up to $89.9 \pm 0.6 \mathrm{mg} \mathrm{HSI}^{-1}$. The HS content was significantly correlated with the total DOC concentration $\left(R^{2}=0.7, D F=56, p<0.001\right)$. Apart from its low HS content, KIMi stands out from the other lakes because of its large HMWS fraction, which is characterized by an extremely high C:N ratio. An analysis of the fluorescence data provided information about the origin of the carbon pools in a fivecomponent model. The excitation and emission loading maxima of the different components are summarized (Supplemental Table 2). As previously described, five-component models (Santín et al., 2009; Koehler et al., 2012; Guo et al., 2014; Mendoza and Zika, 2014) assign component $\mathrm{C} 1$ as an indicator of microbial carbon degradation and C2 as an indicator of terrestrial OM and fulvic acids. C4 was characterized as tyrosine-like and C5 as tryptophanlike. Therefore, C2 correlated with SUVA $\left(r^{2}=0.5, D F=57, p<0.001\right)$ and C1 correlated with HS $\left(R^{2}=0.68, D F=57, p<0.001\right)$. The PCA analysis revealed that $C 1$ and $C 2$ were correlated with SUVA, HS and DOC (Supplemental Figure 1). Component C3 correlated well with C:N, indicating a terrestrial origin or biological degradation. Similarly, the description of C5 as a protein-rich component is consistent with our findings because it correlated well with the HMWS content measured by SEC.

The NMDS analysis of DOM composition (Stress $=0.06$, Stress Fit $r^{2}=0.99$ ) distinguished between two major groups according to their orientation on the first axis, i.e., toward negative or positive values. For the separation on this axis, SUVA can be applied as a threshold variable. All lakes on the positive site have SUVA $>2$, while the sites in the negative range of the first axis have SUVA $\leq 2$. The lake group with SUVA $>2$ was characterized by high DOC concentrations $\left(\geq 17 \mathrm{mg} \mathrm{Cl}^{-1}\right)$, acidic $\mathrm{pH}$, high HS content and a small surface area. The group with SUVA $\leq 2$ contained lakes with high diversity with respect to all abiotic parameters, although all the lakes had alkaline $\mathrm{pH}$ levels. The two extremes on the first axis represent lakes STN, a large oligotrophic lake with the smallest loads of C1 and 
$\mathrm{C2}$, and FuKuSW, a dystrophic peat lake with the highest loads of $\mathrm{C} 1$ and $\mathrm{C} 2$. The extremes on the second axis were in the positive range for $\mathrm{KIMi}$, characterized by the highest HMWS and C5 content, and in the negative range for Kettle holes 259 and 807, which showed the smallest loads in C3.

\section{Phospholipid fatty acid composition analysis}

Benthic PLFA concentrations ranged widely from 1.5 to $47 \mathrm{mg} \mathrm{PLFA} \mathrm{g}^{-1}$. Lakes with a high (>25\%) benthic sediment carbon content had relatively lower PLFA contents (median $=8.2$ mg PLFA g C ${ }^{-1}, S D= \pm 3.4$ ) than lakes with lower benthic sediment carbon contents and

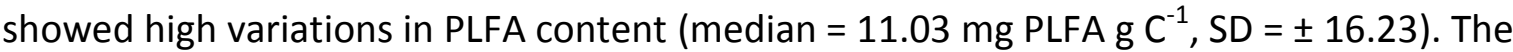
NMDS analysis (Figure: $2 a$; Stress $=0.12$, Stress Fit $r^{2}=0.98$ ) of the benthic PLFA composition yielded a distribution that separated lakes with high sediment carbon concentrations (> 25\%) from those with low $(<3 \%)$ sediment carbon concentrations on the first axis. The correlation between the PLFA and DOM NMDS matrices was significant when tested by the Procrustes test $\left(r^{2}=0.65\right)$ and PROTEST $\left(r^{2}=0.63, p=0.001\right)$. The two lake groups defined by DOM composition using SUVA $=2$ as a threshold value were also separated with one overlap when using PLFA patterns. MANOVA revealed significant differences (DF $=27, \mathrm{pp}<0.001$ ) in fatty acid composition between the two groups. The fatty acids $\mathrm{C} 16: 1 \mathrm{n} 7$, which is a general marker present in all major taxonomic groups, and C18:1n7, which indicates the dominance of eukaryotes in all samples, were the dominant fatty acids in all samples. However, C16:0, which functions as a general biomass marker, was not included in the analysis. Differences between the obtained groups were reflected in higher proportions of short-chain-length fatty acids (C12-C15 including isomers). The low-SUVA group showed higher proportions of the fatty acids C16, C16:1-n7, C18:2n6 and C18:1-n7.

The application of FASTAR revealed a dominance of bacteria (median $=70 \%$, $s d=9.6$ ) over phototrophs ( median $=19.5 \%, s d= \pm 8.2$ ) and fungi $($ median $=9.2 \%, s d= \pm 5.2)$. Chytrids were only detected in low amounts in a few samples. Hyphomycetes, however, were detected in each sample, and data regarding their presence were more consistent, indicating a higher degree of certainty. The biomass of hyphomycetes was higher in lakes with SUVA $\geq$ 2.4 (median $=8.4 \%)$, particularly in the acidic peat bog lakes (median $=13.4 \%$ ), than in those with low SUVA values (median $=7 \%$ ). In contrast, bacterial biomass was higher in low-SUVA lakes (median $=74.3 \%$ in SUVA $\leq 2$ vs. median $=68.6 \%$ in SUVA $>2$ ). All presented 
differences were significant $(p<0.01)$. Lakes KIWu and KIMi showed high $\mathrm{C}$ concentrations in the sediment but below-average percentages of hyphomycetes, indicating that sediment $C$ content is not the sole factor explaining the observed differences between the two major lake groups. The effects of selected parameters on the biomass of fungi and heterotrophic bacteria across all study sites were summarized via CCA (Figure 3); the results indicate that both DOC and sediment C positively affected the hyphomycete biomass and proportion. Bacterial biomass was positively correlated to HMWS and $\mathrm{pH}$ but negatively correlated to SUVA. However, the effect of water column nutrients and metal ions on the benthic heterotrophic biomass composition was minor. Additionally, our analysis involved phototrophs, but they were not affected by any indicator of DOM composition or sediment C content. Ergosterol content relative to total fatty acid content and the biomass of fungi calculated with the Bayesian mixed model showed a significant correlation $\left(R^{2}=0.85\right.$, $\mathrm{p}<0.001, \mathrm{DF}=8$ ). Bacterial cell numbers (cells $/ \mathrm{ml}$ ) did not significantly correlate with calculated bacterial biomass. However, the ratio between bacterial cell counts and fungal ergosterol content, each normalized by the PLFA content of the sample ( $\mu$ g PLFA/ g sediment), showed a highly significant correlation with the F:B ratio determined from the model $\left(R^{2}=0.97, p<0.001, D F=8\right)$.

\section{Stable isotope signatures of OM and PLFA}

The average stable isotope signatures of DOC were $-28.8 \% \pm 1.4 \%{ }^{13} \mathrm{C}$ in all lakes, similar to the values obtained for sediments $\left(-28.9 \pm 1.9 \%{ }^{13} \mathrm{C}\right)$. Compared with these values, the POC $\left(-32.2 \pm 4.1 \%\right.$ o $\left.{ }^{13} \mathrm{C}\right)$ was slightly depleted in ${ }^{13} \mathrm{C}$ by approximately $3.3 \%$ on average (Figure 4). Although the average sediment C and DOC signatures were similar, they were only weakly correlated to each other $\left(r^{2}=0.28\right.$; $\left.D F=15 p<0.05\right)$.

The PLFAs of benthic microbes were depleted in ${ }^{13} \mathrm{C}$ compared with those in bulk sources and showed isotope signatures similar to those of the sediment $C$ (Figure 5 ). This finding was supported by the marker for heterotrophic bacteria biomass i15:0, which had the highest ${ }^{13} \mathrm{C}$ content $\left(-31.7 \pm 4.2 \%{ }^{13} \mathrm{C}\right)$ in the PLFA. The marker $\mathrm{C} 16: 1 \mathrm{n} 7$, which is also an indicator for methanotrophic archaea, showed the strongest depletion in ${ }^{13} \mathrm{C}$ among all PLFAs $(-43.8 \pm 7.4$ $\left.\%{ }^{13} \mathrm{C}\right)$. The fatty acids $\mathrm{C} 16: 0\left(-33.9 \pm 4 \%{ }^{13} \mathrm{C}\right), \mathrm{C} 18: 1 \mathrm{ng}\left(-33.5 \pm 3.8 \%{ }^{13} \mathrm{C}\right)$ and $\mathrm{C} 18: 2 \mathrm{n} 6(-$ $\left.32.3 \pm 3.6 \%{ }^{13} \mathrm{C}\right)$, which can occur in both heterotrophic and phototrophic microorganisms, showed an intermediate ${ }^{13} \mathrm{C}$ depletion. However, the relationships among the ${ }^{13} \mathrm{C}$ depletion 
rates of different fatty acids for all lakes varied. The general marker C16:0 corresponded only weakly with C16:1n7 $\left(r^{2}=0.4 ; p<0.001\right)$ and more significantly with i15:0 $\left(r^{2}=0.77, p<\right.$ 0.001). In addition, the correlation between ${ }^{13} \mathrm{C} i 15: 0$ and $\mathrm{C} 18: 2 \mathrm{n} 6\left(r^{2}=0.75, \mathrm{p}<0.001\right)$ and that between i15:0 and C18:n9 $\left(r^{2}=0.74, p<0.001\right)$ were significant. Our analysis shows that fatty acids are more ${ }^{13} \mathrm{C}$-depleted in sediments with higher $\mathrm{C}$ contents. This effect was most significant for the fatty acid C16:1n7.

\section{Discussion}

Several studies have indicated that higher microbial OM mineralization and respiration rates occur in littoral sediments than in profundal sediments, indicating that littoral sediments are microbial and biogeochemical hotspots (den Heyer and Kalff, 1998; Sala and Güde, 2006; Bergström et al., 2010). Although the importance of DOM for mostly pelagic lake food webs and metabolism has been well studied (e.g. Logue et al., 2015), relationships between the quantity and quality of DOM and benthic microbial community (BMC) composition and activity have rarely been studied. Our results indicate that DOM quantity and quality strongly influence both BMC composition and activity in littoral sediments. Lakes with similar DOM quality are likely to have similar BMC. Based on DOM quality and PLFA composition, two separate groups of lakes were identified, suggesting that using a Bayesian mixed model enabled-for the first time-the exploration of fungal biomass in different lakes. Fungi were present in all systems and were of greater relevance in lakes dominated by allochthonous and processed OM.

\section{Congruence of DOM and PLFA patterns}

The range of DOC concentrations $\left(5-42 \mathrm{mg} \mathrm{Cl}^{-1}\right)$ and the content of $\mathrm{HS}(40-80 \%)$ indicate that the sampled lakes constitute representative lake ecosystems both in central Europe and globally (Kronberg, 2000; Sobek et al., 2007; Tranvik and Wachenfeldt, 2009). Patterns of similarity with respect to DOM composition among the studied lakes were surprisingly consistent with the patterns of similarity among BMC PLFA composition in the lakes (Figure 2 a, b). Interestingly, the nonmetric scaling of the DOM parameters suggests two groups of lakes with extremes in DOM characteristics: 1 ) large oligotrophic lakes, which are dominated by autochthonous DOM sources, and 2) peat bog lakes, which are dominated by high terrestrial OM inflow and relatively aged OM (Figure 2a). Hoostal and Bouzat (2008) found 
that spatial variations in enzyme activity and respiration in lake sediments depend on OM composition in the water column overlying the sediments and suggested that this relationship is also true for the BMC composition. For stream ecosystems, it is widely accepted that the main DOM consumers are benthic heterotrophic bacteria (e.g., Dahm, 1981; Fischer et al., 2002; Wiegner et al., 2015); consequently, DOM quantity and quality hold implications for the BMC composition (Gao et al., 2005). For lake ecosystems, however, only the correlation of DOM quality and composition with bacterial metabolism has been provided to date (Steger et al., 2011; Gudasz et al., 2012; Attermeyer et al., 2013). Specifically, the correlation between HMWS and bacteria indicates the strong influence of autochthonous OM on dynamics of BMC in littoral sediments.

In our study, DOM quality was the main explanatory factor for the differences in BMC composition among the lakes. Furthermore, benthic sediment $\mathrm{C}$ content and DOC were rather loosely related to the BMC composition. A previous study in boreal lakes (Gudasz et al., 2012) indicated that OM origin greatly controls heterotrophic microbial metabolism within lake sediments. Throughout the season, OM quantity and quality of lake sediments vary substantially. For example, aggregation rates of fresh OM show strong seasonality and variability between lakes (Bloesch and Uehlinger, 1986; Hodell and Schelske, 1998; Nõges et al., 1999). Generally, rates are highest during summer and lower in fall and winter. For littoral lake sediments, a strong correlation was observed between allochthonous OM input and benthic OM concentration (Cole et al., 2006). Additionally, littoral sediments are subjected to frequent resuspension depending on turbulence strength and sediment densities (Kleeberg et al., 2013), further affecting the OM quantity and quality of the sediments and hence of the BMC.

\section{PLFA patterns using a mixed model - pros and cons}

Microbial communities can be analyzed using various tools. Although molecular genetic methods offer excellent opportunities to investigate microbial diversity and community structure, they generally do not provide conclusions on the abundance and biomass of the identified taxa. The performance of culture-dependent methods, e.g., colony forming units (CFUs), relies on the culture medium and cultivability of the organisms; thus, they are less suitable for analyses of complex natural microbial communities. The analysis of PLFA provides basic information about microbial diversity and allows for simultaneous and 
reliable microbial biomass quantifications of both fungi and heterotrophic bacteria. The other benefit is the parallel application of stable isotopes, which allows for the detection of carbon sources assimilated into the respective microbial biomass (PLFA). The overall pattern of PLFA has rarely been used to describe microbial communities in lake sediments (Smoot and Findlay, 2001; Liu et al., 2015). To date, most studies have used single PLFA markers to define a subset of specific microbes (Willers et al., 2015). Quantitative differentiation of heterotrophic organisms, particularly aquatic fungi via single PLFA markers, is still limited because of the absence of reliable group-specific PLFA markers. Our study is the first to use the entire PLFA pattern to obtain deeper insights into the fungal distribution in freshwater systems. Verification of our PLFA-based analysis and the Bayesian mixing model included a metabarcoding analysis of fifteen of the twenty sampled lakes. For all tested samples, the presence of fungi with a frequently high diversity could be verified (E. Bourne and L. Ganzert, unpubl. data). Isolation of fungi from lakes STN, FuKuSW and KH259 also resulted in diverse cultures of hyphomycetes (pers. comm. C. Baschien). Comparing the results obtained by mixed models with those obtained by the ergosterol method and bacterial counting proves the high comparability of the ratio between fungi and bacteria. However, the model for describing fungi-bacterial patterns relies on data regarding PLFA patterns described for a number of bacterial and fungal cultures, which could not be adjusted to the complex natural lake communities investigated. Consequently, we did not use the results to quantify the actual F:B ratio, which is reported in other studies, but only to compare the lakes within this study. Future descriptions of PLFA compositions of aquatic bacteria and fungi and further tests of the Bayesian model will probably enhance the possibilities and precision of this method. For example, we detected methanotrophy in certain lakes; however, because of a lack of literature data, we were not able to provide PLFA culture data for type I methanotrophs for the model. However, the modeled patterns of PLFA composition (Figure $2 \mathrm{~b})$ do not suggest that the presence of methanotrophs alters the overall composition of the microbial community significantly because methanotrophs contributed only a small proportion to the overall heterotrophic bacterial biomass.

\section{Environmental influence on benthic microbes}

Our results show that the main proportion of benthic microbial biomass in our lakes consisted of heterotrophic bacteria, which is consistent with our classical understanding that bacteria dominate OC mineralization in lake sediments (Wetzel, 2001). Reports have 
indicated that different bacterial groups consume specific DOM compounds (Cottrell and Kirchman, 2000); therefore, changes in DOM composition result in different bacterial communities. This notion is consistent with our findings that the abundance of heterotrophic bacteria is positively correlated with HMWS and only a small amount of the changes in bacterial abundance were explained by LMWS. The stable isotopes analyses show that DOM is not the primary $\mathrm{C}$ source (Figure 5) of benthic biomass, indicating that the relationship is most likely caused by indirect interactions or that the relevant fraction of DOM altering the community is comparatively small and not necessarily used as a carbon source for biomass production. The majority of DOM in the studied lakes and most other lakes is of allochthonous origin, as indicated by HS and SUVA. The more variable DOM fraction of HMWS generally indicates fresh DOM and might drive the changes in BMC. Indeed, it was recently shown that lake bacteria can consume labile autochthonous carbon sources mainly for respiration and maintain their biomass production from more recalcitrant allochthonous sources (Guillemette et al., 2016). However, they can also use autochthonous sources as their primary source for biomass production (Xu et al., 2014). The case in which the species composition of aquatic bacteria is not altered by changing levels of autochthonous DOM but only their activity (Attermeyer et al., 2014) makes it reasonable to conclude that the actual changes in bacterial biomass are the main reason for the patterns observed in this study. Indeed, our results indicate that OM origin structures the microbial biomass in the lake sediments. The fungal contribution to the total microbial biomass (median $=8 \%$ ) in the littoral sediments is rather small, but it is positively related to the benthic C content, indicators of allochthonous origin and OM age (SUVA, HS). Although many leaf litter degradation studies have been performed, studies on the factors influencing saprophytic fungi in lakes and their sediments are rather scarce (Wurzbacher et al., 2010; Grossart and Rojas-Jimenez, 2016). Therefore, to draw a more general picture, we provide a discussion of soil literature. The increased biomass in acidic peat bog lakes containing aged and preprocessed DOM is consistent with the reported tolerance of fungi to acidic streams and soils (Bååth and Anderson, 2003; Rousk et al., 2009; Krauss et al., 2011) and their ability to degrade recalcitrant OM (Mille-Lindblom and Tranvik, 2003; Grossart and Rojas-Jimenez, 2016). Because increasing F:B ratios in soil indicate increased carbon burial (Malik et al., 2016), we can conclude that a similar mechanism occurs in the observed lakes, with the peat lakes showing the highest rates of carbon burial (Tranvik et al., 2009). The higher 
proportions of fungi observed in this study indicate that low nutrient and low autochthonous DOM contents can increase $\mathrm{F}: \mathrm{B}$ in aquatic ecosystems because the nutrient and nitrogen demands of fungi are lower than those of bacteria (Danger et al., 2016). The relatively low fungal abundances in Lakes KIWu and KIMi, which both have high sediment organic $\mathrm{C}$ contents, indicates that other factors, such as $\mathrm{pH}$ and composition of freshly flocculating $\mathrm{OM}$, are also of great importance for fungal biomass. However, the $\mathrm{pH}$ factor is difficult to separate from DOM quality and concentration because they are often interrelated (Roth et al., 2014). For soils, it was shown that the addition of cellulose first increased the growth of fungi and bacteria, although with a delay for the latter, indicating a supplementary effect of fungal metabolites on bacterial growth. In the same study, adding labile OM and nutrients improved bacterial growth and suppressed fungal growth (Meidute et al., 2008). In littoral marsh lands, aquatic fungi contribute significantly to microbial abundance and carbon turnover (Buesing and Gessner, 2006). Aquatic fungi in lakes have mostly been viewed as degraders of coarse OM (Wurzbacher et al., 2010), but our data suggest that they are also an important part of the littoral BMC and a significant component of $\mathrm{C}$ turnover in lakes, specifically in those with low autochthonous inflow. We can further conclude that fungi in low-nutrient freshwater systems in general supply bacterial activity and are therefore far more important for the overall function of the ecosystem than their biomass indicates.

\section{Isotopy of PLFA and OM}

The isotopic values of single PLFAs were observed to fall within the range reported for various other lakes (de Kluijver et al., 2014; Steger et al., 2015). Furthermore, the signatures of DOC and sediment POC are in the same range observed for boreal lakes (Steger et al. 2015). The PLFAs of bacteria with a heterotrophic origin (i15:0 and a15:0) were less depleted in ${ }^{13} \mathrm{C}$ than eukaryotic and mixed fatty acids. Differences among the isotope signatures of i15:0 and C18:1n9 are consistent with known carbon fractionation during fatty acid synthesis (Monsons and Hayes, 1981). Unfortunately, they do not provide information for determining the differential OM source usage between bacteria and fungi. Additionally, the stronger depletion of OM in the high-SUVA group (Figure 4) indicates that the OM in these lakes is more microbially processed than the OM of the low-SUVA lakes. However, correlations between the isotopic signatures of fatty acids i15:0 and C18:1n9 and the sediment OM signatures suggest that the sediment $\mathrm{OM}$ is indeed the major carbon source for benthic heterotrophic microorganisms. 
In addition to $\mathrm{C}$ sources, the availability of electron acceptors is very important for microbial OM mineralization processes. Although the oxygen availability in the sediments was not measured, it can be assumed to vary greatly between the sampled lakes differing in trophic state and $\mathrm{C}$ bioavailability. The isotopic values of $\mathrm{C} 16: 1 \mathrm{n} 7$ indicate a variable role of methanotrophy between the study sites, with the occurrence of methanotrophy increasing under oxygen depletion. For all lakes, except Lakes SMZ, STN, BrLu, KLK and MGL, which represent five of the six largest lakes in this study and present low contents of OM, a depletion of $\mathrm{C} 16: 1 \mathrm{n} 7$ below ${ }^{13} \mathrm{C}-40 \%$ has been measured, indicating that several microorganisms use methane as a primary carbon source (Steger et al., 2011, 2015; He et al., 2015).

\section{Conclusion}

Littoral benthic microbial communities determined by PLFA patterns revealed a significant relationship with DOM quality, resulting in similar BMC compositions between lakes with similar DOM characteristics. Therefore, different degrees of allochthony together with OM age have a strong effect on the BMC composition in the studied lake ecosystems. These results build on previous studies demonstrating the causes of DOM quality and BMC composition and activity (Hoostal and Bouzat, 2008; Attermeyer et al., 2014; Larson et al., 2014). However, the isotopy of specific fatty acids indicates that benthic OM is still the main carbon source for benthic microorganisms. Our approach using entire PLFA patterns for the simultaneous analysis of living fungal and heterotrophic bacteria revealed comparable results with other methods and supports the use of this method to reliably identify fungal biomass in habitats where fungi are not dominant and co-occur with algae. In our studied lakes, fungi were always present and significantly contributed to the total microbial biomass. Their contribution was always greater in acidic environments with high rates of carbon burial, which strongly affected benthic OM availability. In general, in littoral sediments of various lake ecosystems, the $\mathrm{F}: \mathrm{B}$ ratios are determined by DOM quality, which has important implications for OM stoichiometry and dynamics, including C sequestration. Therefore, expanding our knowledge of the role of fungi and bacteria in aquatic ecosystems will provide new perspectives on aquatic microbial carbon dynamics. 
Acknowledgments:

Elisabeth Bourne, Felix Heeger, Maté Vass and Christiane Baschien took part in the sampling campaign. Eric Hübner, Isaac Kibet and Laszlo Barnyani helped with the sediment sample preparation. Susanne Remus conducted the sediment elemental analysis. The water chemical parameters were analyzed with support from Hans-Jürgen Exner, Antje Lüder and Thomas Rossol. We acknowledge Dominik Zak for conducting the SEC-OCD measurements and advising us on the data interpretation. Barabara Behounek supported the fluorescence measurements and PARAFAC analysis. Angela Krüger supported the PLFA measurements, and Steffen Rühlow conducted the carbon isotope measurements on the fatty acids. Furthermore, we acknowledge Solvig Pinnow for conducting bacterial cell counting and Monika Degebrodt and Mark Gessner for measuring and analyzing ergosterol. The study was performed within the framework of the Mycolink project. All Mycolink colleagues are thanked for partaking in many fruitful discussions. We acknowledge Thomas Mehner and the participants of the course "Scientific Writing" for supporting a first draft of this article via discussion and advising.

Funding:

The study was performed within the framework of the Mycolink project (SAW-2014-IGB) and funded by the Pact for Innovation and Research of the Gottfried Wilhelm Leibniz Scientific Community. Funding was also provided to HPG via the German Science Foundation project MicroPrime (DFG, GR1540/23-1). 


\section{References}

Akinwole, P.O., Lefevre, E., Powell, M.J., and Findlay, R.H. (2014) Unique Odd-Chain Polyenoic Phospholipid Fatty Acids Present in Chytrid Fungi. Lipids 49: 933-942.

Amaral, V., Graeber, D., Calliari, D., and Alonso, C. (2016) Strong linkages between DOM optical properties and main clades of aquatic bacteria. Limnol. Oceanogr. 61: 906-918.

Arce Funck, J., Bec, A., Perrière, F., Felten, V., and Danger, M. (2015) Aquatic hyphomycetes: A potential source of polyunsaturated fatty acids in detritus-based stream food webs. Fungal Ecol. 13: 205-210.

Attermeyer, K., Hornick, T., Kayler, Z.E., Bahr, A., Zwirnmann, E., Grossart, H.P., and Premke, K. (2014) Enhanced bacterial decomposition with increasing addition of autochthonous to allochthonous carbon without any effect on bacterial community composition. Biogeosciences 11: 1479-1489.

Attermeyer, K., Premke, K., Hornick, T., Hilt, S., and Grossart, H.P. (2013) Ecosystem-level studies of terrestrial carbon reveal contrasting bacterial metabolism in different aquatic habitats. Ecology 94: 2754-2766.

Bååth, E. and Anderson, T.H. (2003) Comparison of soil fungal/bacterial ratios in a pH gradient using physiological and PLFA-based techniques. Soil Biol. Biochem. 35: 955-963.

Bannon, C.D., Craske, J.D., and Norman, L.M. (1988) Effect of overload of capillary gas-liquid chromatographic columns on the equivalent chain lengths of C18 unsaturated fatty acid methyl esters. J. Chromatogr. A 447: $43-52$.

Bergström, I., Kortelainen, P., Sarvala, J., and Salonen, K. (2010) Effects of temperature and sediment properties on benthic CO2 production in an oligotrophic boreal lake. Freshw. Biol. 55: 1747-1757.

Bligh, E.G. and Dyer, W.J. (1959) Canadian Journal of Biochemistry and Physiology. 37:

Bloesch, J. and Uehlinger, U. (1986) Horizontal sedimentation differences in a eutrophic Swiss lake. Limnol. Oceanogr. 31: 1094-1109.

Boëchat, I.G., Krüger, A., Chaves, R.C., Graeber, D., and Gücker, B. (2014) Land-use impacts on fatty acid profiles of suspended particulate organic matter along a larger tropical river. Sci. Total Environ. 482-483: 62-70.

Buesing, N. and Gessner, M.O. (2006) Benthic Bacterial and Fungal Productivity and Carbon Turnover in a Freshwater Marsh Benthic Bacterial and Fungal Productivity and Carbon Turnover in a Freshwater Marsh. Appl. Environ. Microbiol. 72: 596-605.

De Carvalho, C.C.C.R. and Caramujo, M.J. (2014) Fatty acids as a tool to understand microbial diversity and their role in food webs of mediterranean temporary ponds. Molecules 19: 5570-5598. 
support of lake food webs by three types of terrestrial organic carbon. Ecol. Lett. 9: 558-568.

Cottrell, M.T. and Kirchman, D.L. (2000) Natural assemblages of marine proteobacteria and members of the Cytophaga-flavobacter cluster consuming low- and high-molecular-weight dissolved organic matter. Appl. Environ. Microbiol. 66: 1692-1697.

Dahm, C.N. (1981) Pathways and Mechanisms for Removal of Dissolved Organic Carbon from Leaf Leachate in Streams. Can. J. Fish. Aquat. Sci. 38: 68-76.

Danger, M., Gessner, M.O., and Bärlocher, F. (2016) Ecological stoichiometry of aquatic fungi: Current knowledge and perspectives. Fungal Ecol. 19: 100-111.

Docherty, K.M., Young, K.C., Maurice, P.A., and Bridgham, S.D. (2006) Dissolved Organic Matter Concentration and Quality Influences upon Structure and Function of Freshwater Microbial Communities. Microb. Ecol. 52: $378-388$.

Fabian, J., Zlatanovic, S., Mutz, M., and Premke, K. (2016) Fungal|[ndash]|bacterial dynamics and their contribution to terrigenous carbon turnover in relation to organic matter quality. ISME Journal, Publ. online 16 December 2016; / doi10.1038/ismej.2016.131 11: 415-425.

Findlay, S., Tank, J., Dye, S., Valett, H.M., Mulholland, P.J., McDowell, W.H., et al. (2002) A cross-system comparison of bacterial and fungal biomass in detritus pools of headwater Instreams. Microb. Ecol. 43: 55-66.

Fischer, H., Sachse, A., Steinberg, C.E.W., and Pusch, M. (2002) Differential retention and utilization of dissolved organic carbon by bacteria in river sediments. Limnol. Oceanogr. 47: 1702-1711.

Frostegård, Å., Tunlid, A., and Bååth, E. (2011) Use and misuse of PLFA measurements in soils. Soil Biol. Biochem. 43: 1621-1625.

Galloway, A., Eisenlord, M., Dethier, M., Holtgrieve, G., and Brett, M. (2014) Quantitative estimates of isopod resource utilization using a Bayesian fatty acid mixing model. Mar. Ecol. Prog. Ser. 507: 219-232.

Galloway, A.W.E., Brett, M.T., Holtgrieve, G.W., Ward, E.J., Ballantyne, A.P., Burns, C.W., et al. (2015) A Fatty Acid Based Bayesian Approach for Inferring Diet in Aquatic Consumers. PLoS One 10: e0129723.

Gao, X., Olape, O.A., and Leff, L.G. (2005) Comparison of benthic bacterail community composition in nine streams. Aquat. Microb. Ecol. 40: 51-60.

Gessner, M.O. and Schmitt, A.L. (1996) Use of Solid-Phase Extraction To Determine Ergosterol Concentrations in Plant Tissue Colonized by Fungi. 62: 415-419.

Gessner, M.O., Swan, C.M., Dang, C.K., McKie, B.G., Bardgett, R.D., Wall, D.H., and Hättenschwiler, S. (2010) Diversity meets decomposition. Trends Ecol. Evol. 25: 372-380. 
del Giorgio, P. a. and Cole, J.J. (1998) Bacterial Growth Efficiency in Natural Aquatic Systems. Annu. Rev. Ecol. Syst. 29: 503-541.

Grey, J., Kelly, A., Ward, S., Sommerwerk, N., and Jones, R.I. (2004) Seasonal changes in the stable isotope values of lake - dwelling chironomid larvae in relation to feeding and life cycle variability. Freshw. Biol. 49: 681-689.

Grossart, H.P. and Rojas-Jimenez, K. (2016) Aquatic fungi: Targeting the forgotten in microbial ecology. Curr. Opin. Microbiol. 31: 140-145.

Gudasz, C., Bastviken, D., Premke, K., Steger, K., and Tranvik, L.J. (2012) Constrained microbial processing of allochthonous organic carbon in boreal lake sediments. Limnol. Oceanogr. 57: 163-175.

Guillemette, F., Leigh McCallister, S., and del Giorgio, P.A. (2016) Selective consumption and metabolic allocation of terrestrial and algal carbon determine allochthony in lake bacteria. ISME J. 10: 1373-1382.

Guo, X.J., He, L.S., Li, Q., Yuan, D.H., and Deng, Y. (2014) Investigating the spatial variability of dissolved organic matter quantity and composition in Lake Wuliangsuhai. Ecol. Eng. 62: 93-101.

Haglund, A.L., Lantz, P., Törnblom, E., and Tranvik, L. (2003) Depth distribution of active bacteria and bacterial activity in lake sediment. FEMS Microbiol. Ecol. 46: 31-38.

Hansen, H.L. and Andresen, K. (1968) Calculation of the retention time of the "air, peak" in gas chromatograms. J. Chromatogr. 34: 246-248.

He, R., Wooller, M.J., Pohlman, J.W., Tiedje, J.M., and Leigh, M.B. (2015) Methane-derived carbon flow through microbial communities in arctic lake sediments. Environ. Microbiol. 17: 3233-3250.

Heinz, M., Graeber, D., Zak, D., Zwirnmann, E., Gelbrecht, J., and Pusch, M.T. (2015) Comparison of organic matter composition in agricultural versus forest affected headwaters with special emphasis on organic nitrogen. Environ. Sci. Technol. 49: 2081-2090.

Helms, J.R., Stubbins, A., Ritchie, J.D., Minor, E.C., Kieber, D.J., and Mopper, K. (2008) Absorption spectral slopes and slope ratios as indicators of molecular weight, source, and photobleaching of chromophoric dissolved organic matter. Limnol. Oceanogr. 53: 955-969.

den Heyer, C. and Kalff, J. (1998) Organic matter mineralization rates in sediments: A within- and among-lake study. Limnol. Oceanogr. 43: 695-705.

Hodell, D.A. and Schelske, C.L. (1998) Production, sedimentation, and isotopic composition of organic matter in Lake Ontario. Limnol. Oceanogr. 43: 200-214.

Hoostal, M.J. and Bouzat, J.L. (2008) The modulating role of dissolved organic matter on spatial patterns of microbial metabolism in Lake Erie sediments. Microb. Ecol. 55: 358-368. 
Huber, S. a., Balz, A., Abert, M., and Pronk, W. (2011) Characterisation of aquatic humic and non-humic matter with size-exclusion chromatography - organic carbon detection - organic nitrogen detection (LC-OCDOND). Water Res. 45: 879-885.

Jobard, M., Rasconi, S., and Sime-Ngando, T. (2010) Diversity and functions of microscopic fungi: A missing component in pelagic food webs. Aquat. Sci. 72: 255-268.

Jones, R.I., Grey, J., Sleep, D., and Quarmby, C. (1998) An assessment, using stable isotopes, of the importance of allochthonous organic carbon sources to the pelagic food web in Loch Ness. Proc. R. Soc. B Biol. Sci. 265: $105-110$.

Jørgensen, N.O.G. and Stepanauskas, R. (2009) Biomass of pelagic fungi in Baltic rivers. Hydrobiologia 623: 105112.

Judd, K.E., Crump, B.C., and Kling, G.W. (2006) Variation in Dissolved Organic Matter Controls Bacterial Production and Community Composition TI - 87. Ecology 87: 2068-2079.

Kleeberg, A., Hupfer, M., Gust, G., Salka, I., Pohlmann, K., and Grossart, H.-P. (2013) Intermittent riverine resuspension: Effects on phosphorus transformations and heterotrophic bacteria. Limnol. Oceanogr. 58: 635-652.

de Kluijver, A., Schoon, P.L., Downing, J.A., Schouten, S., and Middelburg, J.J. (2014) Stable carbon isotope biogeochemistry of lakes along a trophic gradient. Biogeosciences 11: 6265-6276.

Koehler, B., Von Wachenfeldt, E., Kothawala, D., and Tranvik, L.J. (2012) Reactivity continuum of dissolved organic carbon decomposition in lake water. J. Geophys. Res. Biogeosciences 117: 1-14.

Krauss, G.J., Solé, M., Krauss, G., Schlosser, D., Wesenberg, D., and Bärlocher, F. (2011) Fungi in freshwaters: Ecology, physiology and biochemical potential. FEMS Microbiol. Rev. 35: 620-651.

Kritzberg, E.S., Langenheder, S., and Lindström, E.S. (2006) Influence of dissolved organic matter source on lake bacterioplankton structure and function - Implications for seasonal dynamics of community composition. FEMS Microbiol. Ecol. 56: 406-417.

Kronberg, L. (2000) Characterization of aquatic humic substances. In, Keskitalo,J. and Pertti,E. (eds), Limnology of Humic Waters., pp. 7-9.

Kuehn, K. a., Francoeur, S.N., Findlay, R.H., and Neely, R.K. (2014) Priming in the microbial landscape: Periphytic algal stimulation of litter-associated microbial decomposers. Ecology 95: 749-762.

Lange, M., Eisenhauer, N., Sierra, C. a, Bessler, H., Engels, C., Griffiths, R.I., et al. (2015) Plant diversity increases soil microbial activity and soil carbon storage. Nat. Commun. 6: 6707.

Larson, J.H., Frost, P.C., Xenopoulos, M.A., Williams, C.J., Morales-Williams, A.M., Vallazza, J.M., et al. (2014) Relationships Between Land Cover and Dissolved Organic Matter Change Along the River to Lake 
Transition. Ecosystems 17: 1413-1425.

Lehman, P.W., Mayr, S., Mecum, L., and Enright, C. (2010) The freshwater tidal wetland Liberty Island, CA was both a source and sink of inorganic and organic material to the San Francisco Estuary. Aquat. Ecol. 44: 359-372.

Likens, G.E., Steinberg, C.E.W., Timofeyev, M. a., and Menzel, R. (2009) Dissolved Humic Substances: Interactions with Organisms. Encycl. Inl. Waters 747-753.

Liu, L.-X., Xu, M., Qiu, S., and Shen, R.-C. (2015) Spatial patterns of benthic bacterial communities in a large lake. Int. Rev. Hydrobiol. 100: 97-105.

Logue, J.B., Stedmon, C. a, Kellerman, A.M., Nielsen, N.J., Andersson, A.F., Laudon, H., et al. (2015) Experimental insights into the importance of aquatic bacterial community composition to the degradation of dissolved organic matter. ISME J. 1-13.

Malik, A.A., Chowdhury, S., Schlager, V., Oliver, A., Puissant, J., Mellado Vázquez, P.G., et al. (2016) Soil fungal:bacterial ratios are linked to altered carbon cycling. Front. Microbiol. 7: 1247.

Meidute, S., Demoling, F., and Bååth, E. (2008) Antagonistic and synergistic effects of fungal and bacterial growth in soil after adding different carbon and nitrogen sources. Soil Biol. Biochem. 40: 2334-2343.

Mendoza, W.G. and Zika, R.G. (2014) On the temporal variation of DOM fluorescence on the southwest Florida continental shelf. Prog. Oceanogr. 120: 189-204.

Meyers, P.A. and Ishiwatari, R. (1993) Lacustrine organic geochemistry - an overview of indicators of organic matter and diagenesis in lake sediments. Org. Geochem. 20: 867-900 ST-Lacustrine organic geochemistry-an.

Mille-Lindblom, C. and Tranvik, L.J. (2003) Antagonism between bacteria and fungi on decomposing aquatic plant litter. Microb. Ecol. 45: 173-182.

Mille-Lindblom, C., Von Wachenfeldt, E., and Tranvik, L.J. (2004) Ergosterol as a measure of living fungal biomass: Persistence in environmental samples after fungal death. J. Microbiol. Methods 59: 253-262.

Monchy, S., Sanciu, G., Jobard, M., Rasconi, S., Gerphagnon, M., Chabé, M., et al. (2011) Exploring and quantifying fungal diversity in freshwater lake ecosystems using rDNA cloning/sequencing and SSU tag pyrosequencing. Environ. Microbiol. 13: 1433-1453.

Monsons, K.D. and Hayes, J.M. (1981) Biosynthetic Control. Carbon N. Y. 257: 5568-5575.

Murphy, J. and Riley, J.P. (1962) A modified single solution method for the determination of phosphate in natural waters. Anal. Chim. Acta 27: 31-36.

Nõges, P., Tuvikene, L., Nõges, T., and Kisand, A. (1999) Primary production, sedimentation and resuspension in 
large shallow Lake Võrtsjärv. Aquat. Sci. 61: 168.

Olsson, P.A. and Johansen, A. (2000) Lipid and fatty acid composition of hyphae and spores of arbuscular mycorrhizal fungi at different growth stages. Mycol. Res. 104: 429-434.

Premke, K., Karlsson, J., Steger, K., Gudasz, C., von Wachenfeldt, E., and Tranvik, L.J. (2010) Stable isotope analysis of benthic fauna and their food sources in boreal lakes. J. North Am. Benthol. Soc. 29: 13391348.

Romaní, A.M., Fischer, H., Mille-Lindblom, C., and Tranvik, L.J. (2006) Interactions of bacteria and fungi on decomposing litter: Differential extracellular enzyme activities. Ecology 87: 2559-2569.

Roth, V.-N., Dittmar, T., Gaupp, R., and Gleixner, G. (2014) Ecosystem-Specific Composition of Dissolved Organic Matter. Vadose Zo. J. 13: 0.

Roth, V.N., Dittmar, T., Gaupp, R., and Gleixner, G. (2013) Latitude and pH driven trends in the molecular composition of DOM across a north south transect along the Yenisei River. Geochim. Cosmochim. Acta 123: 93-105.

Rousk, J., Brookes, P.C., and Bååth, E. (2009) Contrasting soil pH effects on fungal and bacterial growth suggest functional redundancy in carbon mineralization. Appl. Environ. Microbiol. 75: 1589-1596.

Ruiz-Gonzalez, C., Nino-Garcia, J.P., Lapierre, J.F., and del Giorgio, P.A. (2015) The quality of organic matter shapes the functional biogeography of bacterioplankton across boreal freshwater ecosystems. Glob. Ecol. Biogeogr. 24: 1487-1498.

Sala, M.M. and Güde, H. (2006) Seasonal dynamics of pelagic and benthic (littoral and profundal) bacterial abundances and activities in a deep prealpine lake (L. Constance). Arch. für Hydrobiol. 167: 351-369.

Santercole, V., Delmonte, P., and Kramer, J.K.G. (2012) Comparison of separations of fatty acids from fish products using a 30-m Supelcowax-10 and a 100-m SP-2560 column. Lipids 47: 329-344.

Santín, C., Yamashita, Y., Otero, X.L., Álvarez, M.Á., and Jaffé, R. (2009) Characterizing humic substances from estuarine soils and sediments by excitation-emission matrix spectroscopy and parallel factor analysis. Biogeochemistry 96: 131-147.

Schallenberg, M. and Burns, C.W. (2004) Effects of sediment resuspension on phytoplankton production: teasing apart the influences of light, nutrients and lagal entrainment. Freshw. Biol. 49: 143-159.

Smoot, J.C. and Findlay, R.H. (2001) Spatial and seasonal variation in a reservoir sedimentary microbial community as determined by phospholipid analysis. Microb. Ecol. 42: 350-358.

Sobek, S., Tranvik, L.J., Prairie, Y.T., Kortelainen, P., and Cole, J.J. (2007) Patterns and regulation of dissolved organic carbon: An analysis of 7,500 widely distributed lakes. Limnol. Oceanogr. 52: 1208-1219. 
Stedmon, C. a. and Bro, R. (2008) Characterizing dissolved organic matter fluorescence with parallel factor analysis: a tutorial. Limnol. Oceanogr. Methods 6: 572-579.

Steger, K., Premke, K., Gudasz, C., Boschker, H.T.S., Tranvik, L., and others (2015) Comparative study on bacterial carbon sources in lake sediments: the role of methanotrophy. Aquat. Microb. Ecol. 76: 39-47.

Steger, K., Premke, K., Gudasz, C., Sundh, I., and Tranvik, L.J. (2011) Microbial biomass and community composition in boreal lake sediments. Limnol. Oceanogr. 56: 725-733.

Strandberg, U., Taipale, S.J., Hiltunen, M., Galloway, A.W.E., Brett, M.T., and Kankaala, P. (2015) Inferring phytoplankton community composition with a fatty acid mixing model. Ecosphere 6:.

Strickland, M.S. and Rousk, J. (2010) Considering fungal: Bacterial dominance in soils - Methods, controls, and ecosystem implications. Soil Biol. Biochem. 42: 1385-1395.

Stubbins, a, Lapierre, J., Berggren, M., Prairie, Y.T., Dittmar, T., and del Giorgio, P. a (2014) What's in an EEM? Molecular Signatures Associated with Dissolved Organic Fluorescence in Boreal Canada. Environ. Sci. Technol. 48: 105598-10606.

Taib, N., Mangot, J.F., Domaizon, I., Bronner, G., and Debroas, D. (2013) Phylogenetic Affiliation of SSU rRNA Genes Generated by Massively Parallel Sequencing: New Insights into the Freshwater Protist Diversity. PLoS One 8: 21-26.

Tranvik, L.J., Downing, J. a., Cotner, J.B., Loiselle, S. a., Striegl, R.G., Ballatore, T.J., et al. (2009) Lakes and reservoirs as regulators of carbon cycling and climate. Limnol. Oceanogr. 54: 2298-2314.

Tranvik, L.J. and Wachenfeldt, E. Von (2009) Interactions of Dissolved Organic Matter and Humic Substances. $B$. Sect. 754-760.

von Wachenfeldt, E., Sobek, S., Bastviken, D., and Tranvik, L.J. (2008) Linking allochthonous dissolved organic matter and boreal lake sediment carbon sequestration: The role of light-mediated flocculation. Limnol. Oceanogr. 53: 2416-2426.

Weishaar, J.L., Aiken, G.R., Bergamaschi, B. a., Fram, M.S., Fujii, R., and Mopper, K. (2003) Evaluation of specific ultraviolet absorbance as an indicator of the chemical composition and reactivity of dissolved organic carbon. Environ. Sci. Technol. 37: 4702-4708.

Wetzel, R.G. (2001) Detritus: Organic carbon cycling and ecosystem metabolism. In, Limnology. Elsevier, pp. 731-783.

White, D.C., Davis, W.M., Nickels, J.S., King, J.D., and Bobbie, R.J. (1979) Determination of the sedimentary microbial biomass by extractible lipid phosphate. Oecologia 40: 51-62.

White, D.C. and Tucker, A.N. (1969) Phospholipid metabolism during bacterial growth. J Lipid Res 10: 220-233. 
Wiegner, T.N., Kaplan, L.., Ziegler, S.E., and Findlay, R.H. (2015) Consumption of terrestrial dissolved organic carbon by stream microorganisms. Aquat. Microb. Ecol. 75: 225-237.

Wilkinson, G.M., Pace, M.L., and Cole, J.J. (2013) Terrestrial dominance of organic matter in north temperate lakes. Global Biogeochem. Cycles 27: 43-51.

Willers, C., Jansen van Rensburg, P.J., and Claassens, S. (2015) Phospholipid fatty acid profiling of microbial communities-a review of interpretations and recent applications. J. Appl. Microbiol. n/a-n/a.

Wurzbacher, C., Rösel, S., Rychła, A., and Grossart, H.P. (2014) Importance of saprotrophic freshwater fungi for pollen degradation. PLoS One 9:.

Wurzbacher, C.M., Bärlocher, F., and Grossart, H.P. (2010) Fungi in lake ecosystems. Aquat. Microb. Ecol. 59: 125-149.

Xu, X., Li, W., Fujibayashi, M., Nomura, M., Sakamaki, T., Nishimura, O., and Li, X. (2014) Feedback of threshold via estimating sources and composition of sedimentary organic matter across trophic gradients in freshwater lakes. Sci. Total Environ. 500-501: 373-382.

\section{Figure legends:}

Figure 1: Locations of the studied lentic water bodies in northeast Germany. Seven study sites are magnified on the right side. The adjacent catchment is indicated by a color code (green $=$ forest, pale pink $=$ settlement, red $=$ peat, and yellow $=$ agriculture $).$ Please note the artificial division of Lakes Große Fuchskuhle (GrFU) and Kleiner Gollinsee (KIGO).

\section{Figure 2:}

Clustering of all study sites in the NMDS analysis according to a) DOM composition (Stress: 0.12 , Stress Fit $r^{2}$ : 0.98; determined by size exclusion chromatography, fluorescence and absorbance data) and b) PLFA pattern (Stress: 0.12, Stress Fit $r^{2}: 0.98$ ). The nonmetric scaling of DOM parameters suggests two groups of lakes with extremes in DOM characteristics: 1 ) large oligotrophic lakes, which are dominated by autochthonous DOM sources (blue); and 2) peat bog lakes, which are dominated by high terrestrial OM inflow and aged OM (orange). 
Blue group $=$ SUVA $<2 ;$ orange group $=$ SUVA $>2$ Acronyms are given in Table 1. The respective SUVA values for each lake are depicted in a grey-scale gradient.

Figure 3

Canonical correspondence analysis (CCA - Pillai's Trace 2.1, $p=0.8$ ) of selected parameters and three functional/taxonomic groups as calculated by FASTAR. Similar directions indicate correspondence, and arrow length indicates degree of significance.

\section{Figure 4}

${ }^{13} \mathrm{C}$ isotope signatures of different bulk sources (dissolved organic carbon (DOC), particulate organic carbon (POC), and sediment organic carbon) and fatty acids were compared for two main groups identified by SUVA $>2$ (orange) and SUVA $<2$ (blue). Significance between the two groups is indicated $\left(* * *=p \leq 0.001,{ }^{* *}=p \leq 0.01, *=p \leq 0.05\right.$, n.s. $\left.=p>0.05\right)$

Figure 5

Correlation of the isotope signatures from fatty acids i15:0 (A,D), C18:1n9 (B,E) and C16:1n7 $(C, F)$ with the sediment ${ }^{13} \mathrm{C}$ signature and the sediment carbon content. Correlations at $r^{2}>$ 0.4 are indicated with regression lines: A) $r^{2}=0.48$, B) $r^{2}=0.44$ and F) $r^{2}=0.42$.

\section{Supplemental Figure 1}

Correspondence of various parameters derived from size exclusion chromatography, fluorescence-parallel factor analysis and UV-Vis spectroscopy. Principal component analysis (PCA) reveals three major components. Components 1, 2 and 3 explain $43 \%, 18 \%$ and $10 \%$ of the variance of the data set, respectively. This graph provides an overview of the interdependence and comparability of the parameters provided by the different methods.

\section{Tables:}

\section{Table 1}

Summary of acronyms and geographical, abiotic and biotic core parameters of the study sites. Sites are listed from low to high SUVA values. The solid horizontal line separates the groups identified in Figure 2 a,b. DOC, dissolved organic carbon; SUVA, specific ultraviolet absorption at $254 \mathrm{~nm}$; HMWS, high-molecular-weight substances; and LMWS, low- 
881

882

molecular-weight substances. The abbreviations in surrounding land cover represent forest $(F)$, cropland (C), settlement/city (S), greenland (G), peat (P).

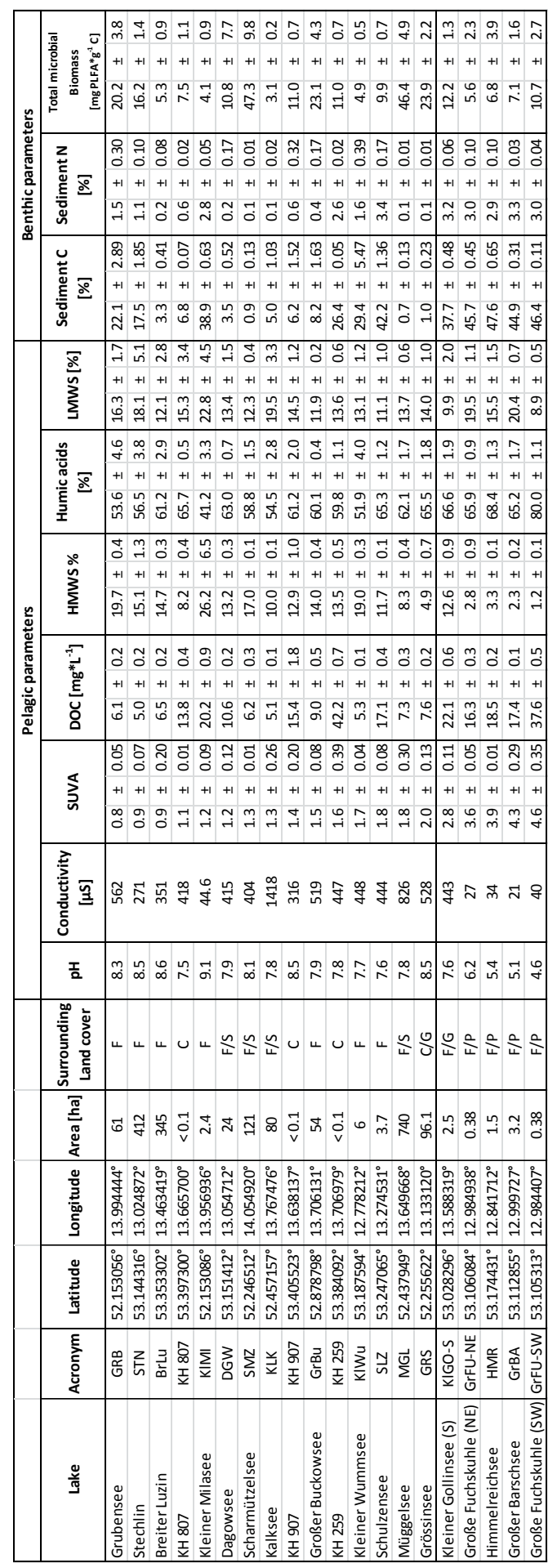

\section{Supplemental Table 1}

Fatty acid composition of various taxa used for mixed model analysis with FASTAR. Values sum to 1 in each column. The presented data are summarized from other publications: De 
887

888

889

Carvalho and Caramujo, 2014 (Bacteria); Strandberg et al., 2015 (Phototrophs); Akinwole et al., 2014 (Chytrids); and Arce Funck et al., 2015 (Hyphomycetes).

\begin{tabular}{|c|c|c|c|c|c|c|c|c|c|c|c|c|c|}
\hline \multirow[b]{2}{*}{$\underset{\frac{N}{\pi}}{\stackrel{n}{\frac{n}{0}}}$} & \multicolumn{4}{|c|}{ Heterotrophic Bacteria } & \multicolumn{2}{|c|}{ Fungi } & \multicolumn{7}{|c|}{ Phototrophs } \\
\hline & 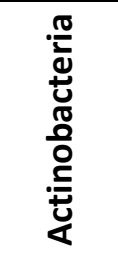 & 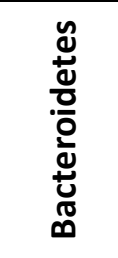 & 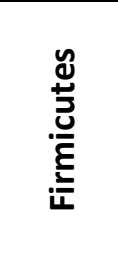 & 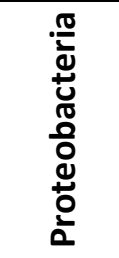 & 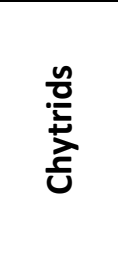 & 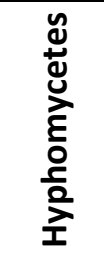 & 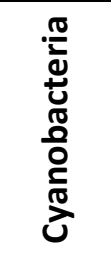 & 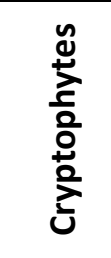 & 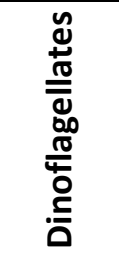 & 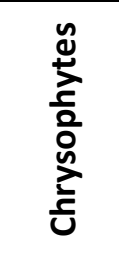 & 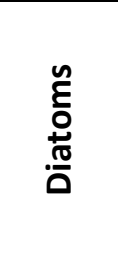 & 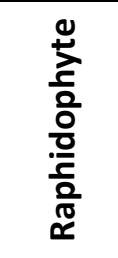 & $\begin{array}{l}\frac{n}{0} \\
\frac{0}{0} \\
\frac{0}{00} \\
\frac{0}{30}\end{array}$ \\
\hline C12 & 0.003 & 0.080 & 0.007 & 0.023 & & 0.001 & & & & & & & \\
\hline C14 & 0.067 & 0.049 & 0.039 & 0.046 & 0.025 & 0.005 & 0.140 & 0.038 & 0.091 & 0.231 & 0.095 & 0.096 & 0.054 \\
\hline C15 & 0.026 & 0.092 & 0.013 & 0.016 & 0.028 & 0.001 & & & 0.008 & & 0.006 & 0.012 & 0.029 \\
\hline C15ai & 0.267 & 0.027 & 0.479 & 0.104 & & & & & & & & & \\
\hline C15i & 0.185 & & 0.279 & 0.066 & & & & & & & & & \\
\hline C16 & 0.239 & 0.650 & 0.125 & 0.663 & 0.235 & 0.218 & 0.308 & 0.213 & 0.368 & 0.107 & 0.173 & 0.220 & 0.148 \\
\hline C17 & 0.010 & 0.027 & 0.003 & 0.010 & 0.025 & 0.001 & & 0.005 & & & & & 0.014 \\
\hline C17i & 0.030 & 0.033 & 0.037 & 0.022 & & & & & & & & & \\
\hline C18 & 0.017 & 0.015 & 0.007 & 0.032 & 0.017 & 0.092 & 0.026 & 0.027 & 0.018 & 0.040 & 0.052 & 0.011 & 0.023 \\
\hline C2O & & & & & & 0.005 & & & & & & & \\
\hline C22 & & & & & & 0.006 & & & & & & & \\
\hline C24 & & & & & & 0.006 & & & & & & & \\
\hline C16:1n9 & & & & 0.002 & & 0.001 & 0.006 & 0.002 & & & & & \\
\hline C16:1n7 & 0.004 & & 0.007 & 0.011 & 0.044 & 0.004 & 0.144 & 0.029 & 0.015 & 0.046 & 0.344 & 0.014 & 0.023 \\
\hline C16:1n5 & & & & & 0.008 & & & 0.002 & & 0.002 & 0.004 & 0.012 & \\
\hline C18:1n9 & 0.152 & 0.028 & 0.005 & 0.005 & 0.149 & 0.257 & 0.013 & 0.024 & 0.194 & 0.033 & 0.015 & 0.007 & 0.034 \\
\hline C18:1n7 & & & & & 0.066 & 0.008 & 0.084 & 0.032 & 0.008 & 0.044 & 0.022 & 0.002 & 0.008 \\
\hline C16:3n4 & & & & & & & & & & & 0.068 & 0.018 & \\
\hline C18:2n6 & & & & & 0.017 & 0.294 & 0.023 & 0.043 & 0.007 & 0.085 & 0.017 & 0.011 & 0.078 \\
\hline C18:3n3 & & & & & 0.111 & 0.104 & 0.189 & 0.242 & 0.002 & 0.124 & 0.001 & 0.119 & 0.143 \\
\hline C18:3n6 & & & & & 0.231 & & 0.041 & & 0.001 & 0.005 & 0.002 & & \\
\hline C18:4n3 & & & & & & & 0.023 & 0.176 & 0.058 & 0.111 & 0.005 & 0.120 & \\
\hline C20:4n6 & & & & & & & & & 0.001 & 0.016 & 0.019 & 0.042 & 0.064 \\
\hline C20:4n3 & & & & & 0.045 & & 0.002 & 0.002 & & 0.007 & & & 0.023 \\
\hline C20:5n3 & & & & & & & & 0.100 & 0.097 & 0.019 & 0.136 & 0.210 & 0.129 \\
\hline C22:5n6 & & & & & & & & 0.037 & & 0.085 & 0.001 & & 0.046 \\
\hline C22:6n3 & & & & & & & & 0.029 & 0.130 & 0.047 & 0.012 & 0.013 & 0.109 \\
\hline
\end{tabular}

890

891

892

893

894

\section{Supplemental Table 2}

Results from parallel factor analysis (PARAFAC). The five components are characterized by excitation and emission maxima.

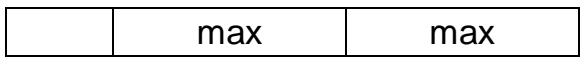




\begin{tabular}{|c|c|c|}
\hline & Excitation & Emission \\
\hline C1 & 295 & 418 \\
C2 & $255 / 370$ & 493 \\
\cline { 1 - 1 } C3 & 285 & 367 \\
\cline { 1 - 1 } C4 & 230 & 325 \\
\cline { 1 - 1 } C5 & 280 & 330 \\
\hline
\end{tabular}

895 